\title{
A study of FNAC of head and neck lesions at a tertiary care centre
}

\author{
Padia B. ${ }^{1}$, Dhokiya M. ${ }^{2}$ \\ ${ }^{1}$ Dr. Bhumi Padia, Tutor, Department of Pathology, GMERS Medical College, Junagadh, ${ }^{2}$ Dr. Mukund Dhokiya, \\ Consultant Pathologist, SRL Diagnostics, Junagadh, Gujarat, India.
}

Corresponding Author: Dr. Mukund Dhokiya, SRL Diagnostics, Junagadh, Gujarat, India. E-mail: dr.bhumipadia@gmail.com

\begin{abstract}
Introduction: The head and neck masses are relatively common pathology. These head and neck masses are evaluated by clinical history and examination with the aid of investigations like FNAC, USG and CT of the region and excision biopsy. Fine Needle Aspiration Cytology (FNAC) is a very simple, quick, inexpensive and minimally invasive technique used to diagnose different types of swellings like lymph node, thyroid, soft tissue and salivary glands in head and neck region. Objectives: It is to assess the frequency and incidence of different sites, age, sex and distribution of inflammatory, benign and malignant lesions. Methods: A retrospective study was conducted at GMERS Medical College \& Hospital, Junagadh, Gujarat from January 2018 to December 2018. Patients between the ages of 35 days to 85 years were enrolled into the study. A total of 139 patients with a head and neck swelling underwent FNAC. Fine needle aspiration diagnosis was correlated with detailed clinical findings and investigations. Result: Out of 139 fine needle aspiration procedures $64.02 \%$ (89 cases) were of lymph node, 18.7\% (26 cases) were of thyroid, $2.87 \%$ from salivary gland(04 cases), $12.94 \%$ (18 cases) from skin and soft tissue swellings. Out of total 139 lesions, 80 (57.55\%) were inflammatory, $48(34.53 \%)$ benign and 09 (6.47\%) were malignant and 02 (1.43\%) were inconclusive. Conclusion: From our study we concluded that FNAC is simple, quick, inexpensive and minimally invasive first line investigation for differential diagnosis of head and neck masses.
\end{abstract}

\section{Introduction}

A swelling is the most likely clinical problem to be encountered in the head and neck region [1]. The evaluation of a neck mass is a common clinical dilemma and a condition to which clinicians routinely encounters. The differential diagnosis in a patient presenting with head and neck mass is often extensive and will vary with age, sex and site. These neck masses are evaluated by a detailed clinical history and examination with the aid of investigations like FNAC,USG and CT of the region and excisional biopsy.

The common pathologies encountered in the head and neck region presenting as a lump are lymphadenitis (specific and non-specific, acute and chronic and reactive), metastatic carcinoma, lymphoproliferative lesions, thyroid swellings (goitre, nodules and cysts and carcinoma), salivary gland swellings (sialadenitis, adenomas and carcinomas) and the skin and soft tissue lesions like lipoma, epidermal (keratinous, dermoid) cysts, benign adnexal tumours, etc.

Manuscript received: $8^{\text {th }}$ December 2018

Reviewed: $19^{\text {th }}$ December 2018

Author Corrected: $26^{\text {th }}$ December 2018

Accepted for Publication: $31^{\text {st }}$ December 2018
Fine needle aspiration cytology is a simple, quick and inexpensive method that is used to sample superficial masses like those found in the head and neck and is usually performed in the outpatient department. It causes minimal trauma to the patient and carries virtually no risk of complications. Masses located within the region of the head and neck, including salivary gland and thyroid gland lesions can be readily diagnosed using this technique $[2,3]$.

FNAC is both diagnostic and therapeutic in a cystic swelling. Fine needle aspiration cytology does not give the same architectural detail as histology but it is quick, relatively painless, requires no anaesthetic, the complications of biopsy are avoided and it can provide cells from the entire lesion as many passes through the lesion can be made while aspirating [4]. The purpose of this study was to see the frequency and distribution ofvarious pathologies detected on FNAC in patients presenting with head and neck swellings and to evaluate the role of FNAC in their diagnosis. It is enrolledfrom the analysis that FNAC is a safe, simple and rapid method that can be performed in diagnosing wide range of head and neck swellings. 


\section{Original Research Article}

\section{Material and Methods}

Place and type of study-It is a retrospective study carried out in Department of Pathology-Central laboratory, GMERS Medical College \& Hospital, Junagadh, Gujarat from January 2018 to December 2018.

Sampling methods-The sampling method used in this study is fine needle biopsy/cytology with aspiration technique.

Sample collection-Detailed clinical history of all the patients were taken related to head and neck swellings and relevant questions were asked to extract the etiology and also about present, past and family history of tuberculosis and history of sexual exposure for syphilis and AIDS.

Patients were explained about the procedure in detail and its advantages and their written consent about the same was taken. The technique was performed in the outpatient department with minimal trauma to the patient without any risk of complication. The area to be aspirated was cleaned with spirit the swelling was fixed with one hand and a 22- 23 gauge needle was inserted at convenient angles to the lesions and multiple hits were made within the lesion with sufficient negative pressure. The needle was removed after releasing the negative pressure and then pressure was applied to the area of aspiration after applying cotton over it to avoid bleeding or hematoma formation.

The material obtained was immediately fixed in methanol for routine haematoxylin and eosin stain and few slides were stained with Pap stain as per the requirement.

Inclusion criteria-In this retrospective study, FNAC was performed in 139 OPD patients presented with swellings in the head and neck regions, All the cases of head and neck swellings send for FNAC from surgical departments of the hospital were included.

Exclusion criteria-The cases of head and neck swellings which were inaccessible were excluded from the study.

Statistical methods-Statistical method used was frequency distribution of various parameters using tables.Statistical Analysis was done and percentages were calculated for estimating frequency of various pathological conditions detected on FNAC in patients presenting with head and neck swellings.

\section{Results}

The present study included 139 cases with the age ranging from 35 days to 85 years out of which 83 (59.71\%) were females and $56(40.29 \%)$ were males. There was higher incidence of lesion in the neck region than in the head region. Lymph node involvement was the commonest constituting 89 cases i.e. $64.02 \%$. Among these lymph node lesions, reactive lymphadenitis is the commonest constituting 38 cases, followed by acute supportive lymphadenitis (22 cases), chronic granulomatous lymphadenitis (17 cases), metastatic lymph node (7 cases), chronic non-specific lymphadenitis ( 2 cases) and single case of angioimmunoblatic hyperplasia of lymphoid tissue.

Thyroid was the second common site to be involved with total 26 cases (18.7\%) out of which23 cases $(88.4 \%)$ were females and 3 cases $(11.6 \%)$ were males. Colloid goitre is the most common thyroid lesion with 17 cases, followed by 05 cases of colloid cyst, 03 cases of follicular neoplasm and a single case of hurthle cell lesion.Out of 18 cases of skin and soft tissuelipoma was the commonest with 8 cases followed by 6 cases of keratinous cyst, 2 cases of simple cyst and single cases of dermoid cyst and benign adnexal tumour each. Out of the 04 salivary gland lesions, 3 cases were of Pleomorphic Adenoma and a single case of sialadenitis. Two cases were inconclusive due to very small size of cervical lesions leading to inadequate material. Reactive lymphadenitis is the commonest inflammatory lesion. Colloid goitre is the commonest benign lesion. Metastatic lymph node is the commonest malignant lesion. Out of 139 FNAs 02 were inconclusive due to insufficient material aspirated because of very small size of lesion.

Table-1: Distribution of lesions as per tissue involved and gender

\begin{tabular}{|l|c|c|c|c|}
\hline Lesions & Female & Male & Total & Percentage \\
\hline Thyroid & 23 & 03 & 26 & $18.7 \%$ \\
\hline Salivary glands & 03 & 01 & 04 & $2.87 \%$ \\
\hline Skin and subcutaneous tissue & 07 & 11 & 18 & $12.94 \%$ \\
\hline Lymph node & 49 & 40 & 89 & $64.02 \%$ \\
\hline Inconclusive & 01 & 01 & 02 & $1.43 \%$ \\
\hline Total & $\mathbf{8 3}$ & $\mathbf{5 6}$ & $\mathbf{1 3 9}$ & $\mathbf{1 0 0 \%}$ \\
\hline
\end{tabular}

Pathology Update: Tropical Journal of Pathology \& Microbiology Available online at: www.pathologyreview.in 593 | P a g e 


\section{Original Research Article}

Table-2: Age wise distribution of various head and neck lesions

\begin{tabular}{|c|c|c|}
\hline Age (years) & No. of cases & Percentage of cases \\
\hline $00-10$ & 15 & $10.79 \%$ \\
\hline $11-20$ & 31 & $22.30 \%$ \\
\hline $21-30$ & 18 & $12.94 \%$ \\
\hline $31-40$ & 28 & $20.14 \%$ \\
\hline $41-50$ & 17 & $12.23 \%$ \\
\hline $51-60$ & 20 & $14.38 \%$ \\
\hline $61-70$ & 5 & $3.59 \%$ \\
\hline $71-80$ & 4 & $2.87 \%$ \\
\hline $81-90$ & 1 & $0.71 \%$ \\
\hline Total & $\mathbf{1 3 9}$ & $\mathbf{1 0 0 \%}$ \\
\hline
\end{tabular}

Table-3: Distribution of various Lymph node lesions

\begin{tabular}{|l|c|c|c|}
\hline Lesions & Female & Male & Total \\
\hline Chronic granulomatouslymphadentis & 10 & 7 & 17 \\
\hline Reactive lymphadenitis & 23 & 15 & 22 \\
\hline Acute suppurative & 09 & 13 & 02 \\
\hline Chronic non-specific lymphadenitis & 02 & 00 & 02 \\
\hline Lymphoproliferative lesions & 00 & 02 & 07 \\
\hline Metastasis & 04 & 03 & 01 \\
\hline Angioimmunoblastic hyperplasia & 01 & 00 & $\mathbf{8 9}$ \\
\hline Total & $\mathbf{4 9}$ & $\mathbf{4 0}$ & \\
\hline
\end{tabular}

Table-4: Distribution of various Thyroid gland lesions

\begin{tabular}{|l|c|c|c|}
\hline Lesions & Female & Male & Total \\
\hline Colloid cyst & 05 & 00 & 05 \\
\hline Colloid Goitre & 14 & 03 & 17 \\
\hline Follicular neoplasm & 03 & 00 & 03 \\
\hline Hurthle cell neoplasm & 01 & 00 & 00 \\
\hline Total & $\mathbf{2 3}$ & $\mathbf{0 3}$ & $\mathbf{2 6}$ \\
\hline
\end{tabular}

Table-5: Distribution of various Salivary gland lesions

\begin{tabular}{|l|c|c|c|}
\hline Lesions & Female & Male & Total \\
\hline Sialadenitis & 01 & 00 & 00 \\
\hline Pleomorphic adenoma & 02 & 01 & 03 \\
\hline Total & $\mathbf{0 3}$ & $\mathbf{0 1}$ & $\mathbf{0 4}$ \\
\hline
\end{tabular}

Table-6: Distribution of various skin and subcutaneous lesions

\begin{tabular}{|l|c|c|c|}
\hline Lesions & Female & Male & Total \\
\hline Lipoma & 04 & 04 & 08 \\
\hline Keratinous cyst & 02 & 04 & 06 \\
\hline Benign Adnexaltumor & 00 & 01 & 01 \\
\hline Benign cyst & 01 & 01 & 02 \\
\hline Dermoid cyst & 00 & 01 & 01 \\
\hline Total & $\mathbf{0 7}$ & $\mathbf{1 1}$ & $\mathbf{1 8}$ \\
\hline
\end{tabular}




\section{Original Research Article}

\section{Discussion}

FNAC, one of the simple, quick and cost- effective methods of evaluating superficial masses found in the head and neck. This technique is outpatient department based and causes minimal trauma to the patient. It is very beneficial in early differentiation of benign from malignant pathology and thus greatly influences the planned treatment. It reduces the cost of hospitalization to the patients. It is the technique which has high degree of accuracy. However doubtful lesions should always be correlated in biopsy specimen study. Further immunohistochemistry and other molecular diagnostic methods helps in arriving at the definite diagnosis.

It can be both diagnostic and therapeutic in case of cystic swellings. So, we undertook the present study to assess the incidence and nature of various head and neck swellings by FNAC. There were no complications of FNAC procedure in head and neck lesions. As well as there were no reported cases of spread of tumour through sinus tract in cases of malignancy.

The most common diagnosis obtained in our study was of reactive lymphadenitis in $27.33 \%$ ( 38 cases) of cases. It was seen in all the age groups. It was common in females compared to males.

Table-7: Showing comparison of distribution of head and neck lesions between our study and other national and international studies

\begin{tabular}{|l|c|c|c|c|}
\hline & Lymph node \% & Thyroid \% & Salivary gland \% & Skin \&Soft tissue \% \\
\hline Our study & 64.02 & 18.7 & 2.87 & 12.94 \\
\hline Shobha [5] & 86 & - & 12 & 02 \\
\hline Shekhar H.[6] & 42 & 18 & 15.5 & 17.5 \\
\hline Sreedevi [7] & 50.32 & 44.07 & 3.28 & 2.3 \\
\hline Pathak [8] & 61.2 & 19.2 & 6.7 & 12.9 \\
\hline S. Khetrapal [9] & 64.1 & 16.9 & 4.1 & 13.8 \\
\hline SanghviAKB [10] & 41 & 37 & 5 & 7 \\
\hline Kapoor S. [11] & 43 & 34 & 15 & 8 \\
\hline Patel D. [12] & 64 & 22.8 & 4.8 & 2 \\
\hline
\end{tabular}

Study done by Sreedevi et al [7] at Andhra Pradesh in 2016 also coincided with our study where out of 304 cases studied $50 \%$ of head neck lesions were from lymph node, in that common lesion seen was reactive lymphadenitis, next was thyroid lesions, in thyroid lesions the commonest diagnosis they arrived was of colloid goiter. The commonest salivary gland lesions they encountered werepleomorphic adenoma. They did not document any malignant salivary gland tumor. The common soft tissue lesions they documented were of epidermal cysts and lipoma.

Study done by SanghviAKB et al [10], Shobha et al [5] and Shekhar et al [6] had reactive lymphadenitis as the commonest lesion comparable to our study.

Study done by SanghviAKB et al [10] and S. Khetrapal et al [9] had maximum inflammatory which is comparable to our study.

Metastasis was the commonest malignant lesion in study done by SanghviAKB et al [10] and AfnanGul et al [13] comparable to our study.

The females out-numbered males in study done by SanghviAKB et al[10] and Kapoor S. et al [11] comparable to our study. Colloid Goiter is the commonest thyroid gland lesion in study done by SanghviAKB et al [10] comparable to our study.Female to male ratio in thyroid gland lesion was 10:1 in study by Patel D. et al [13] which is similar to our study.

Pleomorphic adenoma is the commonest Salivary gland lesion and lipoma is the commonest soft tissue lesion as well as $2 \%$ of FNAs were inconclusive in study by AfnanGul et al [13] comparable to our study. Rathore and team in Panacea conducted the study on head and neck masses on 756 cases. Lymph node swellings were more common followed by thyroid, skin and soft tissue lesions. Salivary gland lesions were least noticed in their study [14].

Pathology Update: Tropical Journal of Pathology \& Microbiology Available online at: www.pathologyreview.in 595 | P a g e 


\section{Original Research Article}

\section{Conclusion}

From our study in which procedure was performed by Dr. Bhumi and manuscript prepared by Dr. Mukund, we concluded that FNAC is simple, quick, inexpensive and minimally invasive first line investigation for differential diagnosis of head and neck masses.

What this study adds to existing knowledge: From our study we came to know about the distribution and nature of various head and neck lesions Most of the swellings occurring in the head and neck region are inflammatory in nature and affect females more commonly than males. Reactive lymphadenitis was the commonest inflammatory lesion; Metastatic carcinoma was the most common malignancy whereas colloid goitre was the most common benign pathology observed in our study. However, advanced studies are required for establishing a more accurate trend of occurrence of head and neck swellings.

Funding: Nil, Conflict of interest: None initiated Permission from IRB: Yes

\section{References}

1. Ahmad T, Naeem M, Ahmad S, et al. Fine needle aspiration cytology (FNAC) and neck swellings in the surgical outpatient. J Ayub Med CollAbbottabad. 2008 Jul-Sep;20(3):30-2.

2. Gamba PG, Messineo A, Antoniello LM, et al. A simple exam to screen superficial masses: fine-needle aspiration cytology. Med PediatrOncol. 1995 Feb;24 (2): 97-9.

3. Lee JC, Siow JK. Thyroid surgery--the Tan Tock Seng Hospital otolaryngology experience.Ann Acad Med Singapore. 2002 Mar;31(2):158-64.

4. Kirk RM, Ribbans WJ. Clinical Surgery in General. 4th edition, Edinburgh: Elsevier; 2004.

5. Shobha SN, Rajashekar YR. Role of Fine needle aspiration cytology in Head and neck lesions Indian Journal of Pathology and Oncology, July-September 2017;4(3):408-412
6. Shekhar H, Kaur A, Agrawal P, Pancharia A, Jadeja P. Fine needle aspiration cytology in head and neck swellings: a diagnostic and therapeutic procedure. Int J Res Med Sci 2014;2(4):1667-71

7. Sreedevi P, Kishore Kumar, Parankusa N C. Diagnostic Role of FNAC in evaluation of Head and Neck lesions. Journal of Medical and Dental sciences. 2016;15 (9):11-13

8. Pathak R, Prasad KBR, Rauniyar SK, Pudasaini S, Pande K, Koirala S, Kafle, Jha A, Chalise S, Basnyat AS. Fine needle aspiration cytology of head and neck lesions and its correlation with histopathology. Journal of Pathology of Nepal 2016;6(1):985 -989

9. Khetrapal S, Jetley S, Jairajpuri Z, Rana S, Kohli S. FNAC of head \&neck regions and its utility in clinical diagnosis: A study of 209 cases.Nat J. Med Res 2015;5 (1):33-8

10. Sangavi AKB, Itagi IR, Choudhari SY, Venkatesh U. Evaluation of FNAC of head and neck swellings: a retrospective study. Int J Otorhinolaryngol Head Neck Surg 2018;4 (1):189-92.

11. Kapoor S, Bagga PK, Rupesh S, Singh A, Kumar A, Singh H. Diagnostic accuracy of fine needle aspiration cytology in palpable lesions of head and neck in comparison to histopathology. International Journal of Contemporary Medical Research 2017;4(2):449-453

12. Patel DN, Patel PB, Patel HV, Gandhi TJ. Fine needle aspiration cytology role in head and neck lesions. IAIM, 2015; 2(8):99-104

13. AfnanGul, Vani B.R., Srinivasa Murthy V. Fine Needle Aspiration Cytology Profile of Head and Neck Lesions ina Tertiary Care Hospital. Indian Journal of Pathology 2017;6(2):372-377

14. Rathore H, Jethani N, Panchori G, Bansod P. RatnawatKalpana. Cytomorphology of Head and Neck lesions: A study in tertiary care hospital. Panacea journal of Medical Sciences. 2015;5 (3):145-149.

\section{How to cite this article?}

Padia B., Dhokiya M. A study of FNAC of head and neck lesions at a tertiary care centre. Trop J Path Micro 2018;4(8):592-596.doi:10.17511/jopm.2018.i08.08. 